\title{
Islam and Evolution: A Defense
}

İslam ve Evrim: Bir Savunma

\begin{abstract}
Enis DOKO
Associate Professor, İbn Haldun University, Humanities and Social Sciences School, İstanbul/Türkiye enisdoko@gmail.com | orcid.org/0000-0001-9021-6021 | ror.org/02y5xdw18
\end{abstract}

\author{
Article Information \\ Article Type \\ Research Article \\ Date Recieved \\ 28 October 2021 \\ Date Accepted \\ 28 December 2021 \\ Date Published \\ 31 December 2021 \\ Plagiarism
}

This article has been scanned with iTenticate software. No plagiarism detected.

Ethical Statement

It is declared that scientific and ethical principles have been followed while carrying out and writing this study and that all the sources used have been properly cited (Enis Doko).

Licensed under CC BY-NC-ND 4.0 license. 


\begin{abstract}
Arguably most crucial issue in science-religion interaction in the Muslim context is the relation of Islam and the NeoDarwinian theory of evolution. Muslim scholars are divided into two main camps. On the one hand, Muslim scholars with more traditional inclinations think that Islam conflicts with evolution. On the other camp, we have more scientifically oriented Muslim thinkers who think that theory of evolution is fully compatible with Islam. These thinkers, primarily practicing scientists, usually either offer a metaphorical reading of some of the Qur'anic verses or reinterpret them. In this paper, I will take a middle ground and try to evaluate the compatibility of the traditional reading of Qur'an with the Neo-Darwinian theory of evolution without invoking metaphorical reading or reinterpretation. We will also accept the standard scientific narrative without any distortion. First, I will defend the claim that the scriptural creation narrative is incompatible with the theory of evolution is analogous to the problem of evil, i.e., the claim that evil is incompatible with the God of classical Theism. Using this analogy, I will argue that rather than trying to find a complete and plausible account of how the Qur'anic narrative and the theory of evolution can both be true, we should search for more modest approaches which just aim to show that two accounts are compatible-similar to defenses in the context of the problem of evil. After sketching both the scientific as well as the scriptural accounts, and after arguing that the only potential conflict lies in the common ancestry thesis, I will present two such defenses which aim to show the compatibility of the Qur'anic narrative with the theory of evolution. First, the "double creation defense" involves scenarios at which Adam is created twice, once in Paradise, which is described by scripture, and the other one on Earth described by evolutionary science. As such, both accounts can be true at the same time and therefore are compatible. Second, "the multiple ancestors defense" argues that God might have created Adam out of clay directly, with his descendants reproducing with evolved homo sapiens. As such, both creation narratives coexist without inconsistency.
\end{abstract}

Keywords: Evolution, Human evolution, Evolutionary biology, Islam, Problem of evil, Adam and Eve.

\title{
Öz
}

Müslüman bağlamında bilim-din etkileşiminde muhtemelen en can alıcı konu, İslam ve Neo-Darwinci evrim teorisi arasındaki ilişkidir. Müslüman alimler iki ana kampa ayrılır. Bir yandan, daha geleneksel eğilimlere sahip Müslüman düşünürler, İslam'ın evrimle çeliştiğini düşünüyorlar. Diğer tarafta, evrim teorisinin İslam'la tamamen uyumlu olduğunu düşünen daha bilimsel yönelimli Müslüman düşünürlerimiz var. Başta bilim insanları olmak üzere bu düşünürler, genellikle Kuran ayetlerinin bazılarının mecazi bir okumasını sunarlar ya da onları yeniden yorumlarlar. Bu makalede, ben orta yolcu bir yaklaşım tercih edecek ve mecazi okumaya ya da yeniden yorumlamaya başvurmadan, geleneksel Kuran okumasının Neo-Darwinci evrim teorisi ile uyumluluğunu göstermeye çalışacağım. Standart bilimsel anlatıyı da herhangi bir çarpıtmaya maruz bırakmadan kabul edeceğim. ìlk olarak, kutsal kitaptaki yaratılış anlatısının evrim teorisiyle bağdaşmadığı iddiasının kötülük sorununa, yani kötülüğün klasik Teizm'in Tanrısı ile bağdaşmadığı iddiasına, benzediğgini savunacağım. Bu analojiyi kullanarak hem Kuran anlatısının hem de evrim teorisinin nasıl doğru olabileceğine dair eksiksiz ve makul bir açıklama bulmaya çalışmak yerine, sadece bu iki açıklamanın birbiri ile çelişmediğini göstermeyi amaçlayan daha mütevazı yaklaşımlar aramamız gerektiğini iddia edeceğim-yani kötülük sorunu bağlamındaki savunmalara benzer bir yaklaşım geliştirmeye çalışacağım. Hem bilimsel yaratılış anlatısı hem de Kuran'daki yaratılış anlatısı özetledikten sonra ve olası tek çelişkinin ortak ata tezinde olduğunu savunduktan sonra, Kuran anlatımının evrim teorisiyle uyumluluğunu göstermeyi amaçlayan bu tür iki savunma sunacağım. Birinci savunma, "çifte yaratılış savunması", Adem'in, kutsal kitapların tarif ettiği Cennet'te ve evrim biliminin tarif ettiği Dünya'da olmak üzere iki kez yaratıldığı senaryoları içerir. Bu nedenle, her iki yaratılış anlatısı da aynı anda doğru olabilir ve bu nedenle ikisi bir biri ile tutarlıdır. İkincisi, "çoklu ata savunması", Tanrı'nın Adem'i doğrudan topraktan yaratmış olabileceğini ve onun soyundan gelenlerin evrimleşmiş homo sapiens ile ürediğini öne sürer. Bu nedenle, her iki yaratılış anlatıları da tutarsızlık olmadan bir arada kabul edilebilir.

Anahtar Kelimeler: Evrim, İnsan evrimi, Evrimsel biyoloji, İslâm, Kötülük sorunu, Adem ve Havva. 


\section{Introduction}

Arguably most crucial issue in science-religion interaction in the Muslim context is the relation of Islam and the Neo-Darwinian theory of evolution. Muslim scholars are divided into two main camps. On the one hand, Muslim scholars with more traditional inclinations, such as Seyyed Hossein Nasr ${ }^{1}$, Nuh Ha Mim Keller ${ }^{2}$, Yashir Qadhi and Nazir Khan ${ }^{3}$, think that Islam conflicts with evolution. These scholars either reject the theory of evolution entirely or exclude humans from it. Some of these scholars acknowledge the theory of evolution as a valid scientific theory but embrace scientific anti-realism. Such thinkers claim the inconsistency of Islam and evolution. On the other camp, we have more scientifically oriented Muslim thinkers such as Rana Dajani ${ }^{4}$, Caner Taslaman $^{5}$, Nidhal Guessoum ${ }^{6}$, and Basil Altaie ${ }^{7}$, who think that theory of evolution is fully compatible with Islam. These thinkers, primarily practicing scientists, usually either offer a metaphorical reading of some of the Qur'anic verses or reinterpret them. Such thinkers claim the consistency of Islam and evolution ${ }^{8}$.

The first camp's views, perhaps with the exception of the anti-realist approach, contradict modern science and as such does not appeal to Muslim scientists. On the other hand, the second group's approach, while in accord with modern science, usually fails to convince the more traditionally oriented scholars who insist on more traditional readings of the scripture. While I sympathize with this second camp, I believe we need a more balanced approach to the issue to convince wider audiences on the compatibility of Islam and evolution. In this paper, I will try to take the middle ground and argue that the traditional readings of the Muslim scriptures are compatible with the theory of evolution.

Unlike the above-mentioned thinkers, I am not going to offer a particular reading of the Qur'an which is compatible with evolution. Instead, I will make an analogy with the problem of evil and develop a defense of the compatibility of Islam and evolution: a possible but not necessarily plausible scenario in which both the scientific theory of evolution and the literal reading of the Qur'an consistently coexist. In the next section, I will develop the analogy with the problem of evil and introduce the terminology, then summarize the central tenets of the theory of evolution. In the following section, I will outline the Qur'anic creation narrative. In the last section, I will present two defenses of the compatibility of Islam and evolution.

Seyyed Hossein Nasr, "On the Question of Biological Origins." Islam and Science 4/2 (2006), 181-197. Nuh Ha Mim Keller, Sea Without Shore: A Manual of the Sufi Path (Amman: Sunna Books, 2011), 350-356.

Yaser Qadhi and Nazir Khan "Human Origins: Theological Conclusions and Empirical Limitations." (2019), Yaqeeninstitute (Accessed July 29, 2021).

Rana Dajani, “Evolution and Islam's Quantum Question.” Zygon: Journal of Religion and Science, 47/2 (2012), $343-353$.

Caner Taslaman, Can a Muslim Be an Evolutionist? (Istanbul: Istanbul Yayınevi, 2020).

Nidhal Guessoum, Islam's Quantum Question: Reconciling Muslim Tradition and Modern Science (London: I.B. Tauris, 2011), 271-326.

Basil Altaie, The Divine Word and The Grand Design: Interpreting the Qur'ān in the Light of Modern Science. (Manchester: Beacon Books, 2018), 131-135.

$8 \quad$ For detailed review of various Muslim opinions on Islam and evolution reader may refer to, Shoaib Malik, Islam and Evolution: Al-Ghazāli and the Modern Evolutionary Paradigm. (New York: Routledge, 2021), 106-155. 


\section{An analogy with the Problem of Evil}

For a person who believes in evolution, the inconsistency claim can be interpreted as an argument against Islamic theism. This argument, which I will term "the Problem of Evolution for Islamic Theism," can be expressed in the following simple form:

1. If Islamic Theism is true, then evolution is false. (Inconsistency thesis)

2. Evolution is true. (Evolutionary Realism)

3. Therefore, Islamic Theism is false.

The first premise, the inconsistency thesis, holds that Islamic Theism is inconsistent with the scientific theory of evolution. This premise can be defended in various ways. One might argue, for example, that the pain and suffering in evolution are inconsistent with the benevolent, omnipotent and omniscient God of Islamic theism. Or one might argue that the randomness in evolution is inconsistent with divine providence. While all these claims are worth considering, most claim that the creation model narrated in the Qur'an is inconsistent with evolution. This is the primary reason defenders of the inconsistency thesis reject the theory of evolution. The second premise, Evolutionary Realism, holds that the main thesis of evolution, which I will define in the next section, is true.

A Muslim, then, will have to deny one of the two premises of the above argument. Defenders of the consistency thesis will reject the first premise, while the defenders of the inconsistency thesis will target the second premise.

In this paper, I will target the first premise by way of an analogy with the Logical Problem of Evil ${ }^{9}$, which can be expressed in the same form as the above argument:

1. If Classical Theism is true, then there is no evil. (Inconsistency thesis)

2. Evil exists. (Evil Realism)

3. Therefore, Classical Theism is false.

In this paper, by classical theism, I mean that there is a God who is omnipotent, omniscient, and perfectly good. The basic idea behind the first premise is that omnipotent being would be able to prevent all the evil in the world, an omniscient being would know how to eliminate it, and perfectly good being would want to eliminate it. Hence, if there were an omnipotent, omniscient, and perfectly good God, He would want to prevent evil, would know how to prevent it, and would be able to prevent it. Thus, if the God of classical theism exists, then no evil exists; the God of classical theism is logically inconsistent with evil. The second premise claims that evil exists.

While a few deny the existence of evil, most theists will deny the first premise and try to show that the existence of evil is consistent with classical theism. There are two distinct strategies that can be deployed to respond to the inconsistency thesis in the problem of evil, a defense or theodicy ${ }^{10}$ (Tooley 2019). A defense attempts to refute the logical problem of evil by showing that there is no logical incompatibility between the existence of evil and the existence of God. A

J. L. Mackie, "Evil and Omnipotence." Mind, 64 (1955), 200-212.

10 Michael Tooley. "The Problem of Evil", The Stanford Encyclopedia of Philosophy (Spring 2019 Edition), Edward N. Zalta (ed.), (Accessed July 29, 2021). 
defense does not require a plausible explanation of why God allows evil, it is sufficient to construct a coherent story in which both evil and God coexist. This story need not be true since a false but coherent story is sufficient to show logical compatibility. For example, Alvin Plantinga uses the so-called free-will defense against the logical problem of evil ${ }^{11}$. According to the free-will defense, God values free will and has granted free will to the creatures such as humans and demons. The evil in the world is a result of the misuse of free will by humans in case of moral evils and by demons in case of natural evils ${ }^{12}$. While Plantinga does not believe that natural evil is caused by demons, it is a consistent story that successfully defuses the logical problem of evil. On the other hand, a theodicy is more ambitious: it tries to provide not only coherent but also a plausible story of why evil and God coexist in our world. In other words, it tries to provide the true justification for the existence of evil given the existence of the God of classical theism.

Why do I refer to the analogy between the problem of evil and the Problem of Evolution for Islamic Theism? I want to borrow the technical terminology from the problem of evil, that is the theodicy and defense approaches. That is why I introduced the problem of evil and relevant technical terminology. I believe the logical consistency thesis can be defended for Islam and evolution by either by developing a theodicy or defense. Most defenders of consistency try to find a plausible way to affirm both the scripture and the theory of evolution. Their approaches resemble theodicies. But I believe this is a too ambitious project and we lack enough scriptural data for such project. Therefore in this paper, I will argue for the compatibility thesis using a more modest approach that resembles a defense against the logical problem of evil. This approach has two advantages. First, we will be able to put forward more than one scenario; as we know from the literature on the problem of evil, multiple defenses are possible. Second, we will be able to maintain both a traditional reading of the Qur'an and the integrity of modern science without committing ourselves to some particular theology or hermeneutical strategy. In the next section, I will briefly summarize the central claims of the theory of evolution. Then I will summarize the traditional reading of the creation story Adam as outlined in the Qur'an. In the final section, I will develop several scenarios in which both scientific and scriptural creation stories coexist.

\section{Summary of the Theory of Evolution}

In order to assess the inconsistency thesis, we need to understand both the scriptural and scientific creation stories. In this section, I will briefly outline the essential claims of the theory of evolution. Most creationists fail to recognize that evolution is not a single claim; like every scientific theory, it is multi-propositional. Islamic theism may not conflict with all the aspects of the theory. Therefore, it is crucial to lay down the central tenets of evolution and evaluate each of them individually to determine possible conflicts with the creation stories in the scriptures.

The basic ideas of the theory of evolution can be summarized in six theses. While I do believe that they capture the heart of the theory, they are, of course, incomplete and underdeveloped.

Alvin Plantinga. God, Freedom, and Evil (Grand Rapids, MI: Eerdmans: 1977).

Plantinga, God, Freedom, and Evil, 58. 
1. Old Earth. The theory of evolution assumes that the universe, the earth and life are old. The age of the earth is estimated using radiometric age-dating to be 4.54 billion years ${ }^{13}$. The oldest fossils of single-celled organisms go as back as 3.5 billion years ago ${ }^{14}$. Modern humans or homo sapiens emerged around 200.000-300.000 years ago ${ }^{15}$. The Qur'an does not give any specific date for the creation of the earth, life, or humans. Therefore, the old earth thesis is compatible with Islam.

One possible objection for the old earth thesis will be to point to verses in Quran which state that universe was created in six days such as:"And We did certainly create the heavens and earth and what is between them in six days, and there touched Us no weariness." ${ }^{16}$

Yet this objection can be easily countered as Quran uses the word day (yawm) for longer periods of time such as thousand or fifty thousand years. Here are the relevant verses: "He arranges [each] matter from the heaven to the earth; then it will ascend to Him in a Day, the extent of which is a thousand years of those which you count." "The angels and the Spirit [i.e., Gabriel] will ascend to Him during a Day the extent of which is fifty thousand years." ${ }^{18}$

These two verses clearly demonstrate that one day can mean different periods of time, hence six days need not mean 24 hours.

2. Microevolution. Microevolution is evolution within a single species, or more precisely within a single population ${ }^{19}$. A population is a group of organisms that share a gene pool, i.e., they can interbreed with each other. This thesis states that gene frequency can change within a population. In other words, the characteristic of the population can change with time. Again the Qur'an contains no verse that claims that species are fixed and cannot change over time. Thus, there is no reason to think that microevolution is incompatible with Islam.

3. Macroevolution. Macroevolution expresses the change across the species. One important form of macroevolution is speciation ${ }^{20}$. Since speciation is usually denied by creationists, we will focus on it. In order to understand speciation, we need first to understand what species are. Species are the smallest set of organisms that are able to produce offspring, and members of a species are able to reproduce successfully. Populations are a subgroup of the species which live in the same particular area. Speciation, then, is the formation of a new species. Speciation happens when a reproductive barrier emerges that prevents two groups of organisms from interbreeding. Some creationists, while acknowledging microevolution, deny speciation. Again, the Qur'an does not speak of speciation. Some defenders of the inconsistency thesis, such as Seyyed Hossein Nasr, deny the possibility of speciation. But his theological arguments against speciation seem to be

\footnotetext{
13 G. Brent Dalrymple, "The age of the Earth in the twentieth century: a problem (mostly) solved". Geological Society, London, Special Publications. 190/1 (2001), 205-221.

14 J. William Schopf, "Fossil evidence of Archaean life". Philosophical Transactions of the Royal Society B. 361/1470 (2006), 869-885.

15 Douglas Futuyma and Mark Kirkpatrick, Evolution (New York: Oxford University Press, 2018), 555.

16 The Quran, Trans. Saheeh International, (Riyad: Saheeh International, 1997), Qāf 50/38.

17 As-Sajdah 32/5.

$18 \quad$ Al-Ma'ārij 70/4.

19 Futuyma and Kirkpatrick, Evolution, 516.

20 Futuyma and Kirkpatrick, Evolution, 213-243.
} 
based on his Platonist philosophy rather than any specific verse in the Qur'an ${ }^{21}$. As we will see in the next section, Muslims have traditionally believed that the first human, Adam, was created directly out of clay. But even if we accept this narrative, Muslims need not deny speciation in general. Thus, speciation as a concept is compatible with Islam.

4. Natural selection. Natural selection is the main mechanism through which species adapt to their environment and change $\mathrm{e}^{22}$. Individual organisms in a given population have different heritable traits. Some traits are more suitable to the environment they live in and provide a survival advantage to the individual. Organisms with advantageous heritable traits survive longer and so have more chances to reproduce and pass on the beneficial traits to their offspring. Over time as these more advantageous traits become more common within the population, we say that population evolves. This is the process of natural selection. Again, the Qur'an does not speak of natural selection; hence there is no scriptural reason to oppose $\mathrm{it}^{23}$.

5. Neo-Darwinism. Broadly Neo-Darwinism is the integration of Darwin's theory of evolution by natural selection with genetics ${ }^{24}$. According to modern genetics, there is a molecule called DNA which is the basic hereditary material, which affects the look, behavior, and physiology of the organism. Traits are stored in this molecule and passed on by it to the offspring. Changes in the DNA of an organism are called mutations, the source of the genetic variation. Mutations happen independently of the needs of the species, which is usually expressed by the phrase "mutations are random". Therefore, mutations can be neutral, beneficial or harmful for the organism's survival as there is no mechanism in the organism that detects what kind of mutations would be beneficial and causes it to occur. Whether the random nature of mutations is compatible with the providence of God is an interesting philosophical question. ${ }^{25}$ I believe that it is, but since I am focusing just on direct scriptural consistency in this paper, I will not comment on $\mathrm{it}^{26}$. It is sufficient to state that these modern terms such as mutation, genetics, DNA are obviously absent

Malik, Islam and Evolution, 116.

Futuyma and Kirkpatrick, Evolution, 55-75.

One may argue that while there is no scriptural reason to deny natural selection it implies that process is unguided, as such in conflict with divine providence. In this article I will not adress philosophical objections based on evolution against theism. But I want to point out to a quote from non-theist biologist Sahotra Sarkar: "The critical point is that the theory of natural selection is neutral about whether the origin of variation is blind (undirected) or not; all natural selection requires are (i) the existence of variation (whether or not these arose blindly), (ii) fitness differences between the variants, and (iii) inheritance of the variation (Lewontin 1970). Given these assumptions, the fitness differences lead to directional selection resulting in increased adaptation between an organism and its environment." (Sarkar, "Review of Seeking God in Science: An Atheist Defends Intelligent Design")

$24 \quad$ Futuyma and Kirkpatrick, Evolution, 16.

25 For the problem and the possible solutions see Kelly James Clark and Jeffrey Koperski, Abrahamic Reflections on Randomness and Providence, (Palgrave Macmillan, 2021 forthcoming).

26 Random used in biology is technical term which need not mean unguided. Here is a definiton of one of the most prominent philosopher of biology who is non-theist Earnst Mayer: "When it is said that mutation or variation is random, the statement simply means that there is no correlation between the production of new genotypes and the adaptational needs of an organism in a given environment." (Ernst Mayr, Towards a New Philosophy of Biology: Observations of an Evolutionist (Cambridge: Harvard University Press, 1988),. 98.). This definition is is compatible with God who uses law of nature to produce living things. 
in the Qur'an. Again, there is no verse that is related to the Neo-Darwinian thesis. Thus, it is also compatible with the narrative of the Qur'an.

6. Common Ancestry. According to this thesis, all living things are descendants of a common ancestor--every species shares a common ancestor from which both evolved via the processes discussed above ${ }^{27}$. Even humans share a common ancestor with other living things. We did not evolve from monkeys, as is often claimed by critics, but we share a common ancestor with other primates, other mammals, and even plants. Common ancestry, in my opinion, is the only potentially conflicting thesis with the Qur'an. But if we exclude humans, common ancestry is clearly compatible with the Qur'an; no verse in Qur'an states or implies that non-human living things cannot share a common ancestor. However, traditionally Adam's creation story is thought to be in conflict with common ancestor thesis. We will analyze the relevant Qur'anic verses in the next section.

With the possible exception of humans sharing a common ancestor with all living things, the literal reading of the Qur'anic narrative does not contradict the theory of evolution. There is no scriptural reason to oppose the theory of evolution in general. Minimally, Muslims could easily embrace the theory of evolution with the exception of humans. However, excluding human evolution conflicts with modern science-there is powerful genetic evidence that demonstrates that humans share a common ancestor with the other primates, for example, and all other living creatures $^{28}$. I think we can develop at least two objections to the conflict thesis. But before presenting those objections, let us review Adam's creation story as presented in the Qur'an.

\section{Creation of humans in Qur'an}

Unlike the Hebrew Bible/Old Testament, the Qur'an lacks a detailed chronological story of the creation of Adam and Eve. Since the name of Eve is not explicitly mentioned in the Qur'an, we will focus our discussion on Adam. The first thing to note is that Qur'an makes references to humans and Adam's creation from the earth, clay, dust, or mud"29: "O people, if you should be in doubt about the Resurrection, then [consider that] indeed, We created you from dust, then from a spermdrop, then from a clinging clot, and then from a lump of flesh, formed and unformed - that We may show you." "'30 "He created man from clay like [that of] pottery." 131 "And We did certainly create man out of clay from an altered black mud." ${ }^{132}$ "And to Thamūd [We sent] their brother Șâlih. He said, "O my people, worship Allah; you have no deity other than Him. He has produced you from

\footnotetext{
$27 \quad$ Futuyma and Kirkpatrick, Evolution, 14.

28 For detailed presentation of genetic evidence in support of humans sharing common ancestor with other living things see Graeme Finlay, Human Evolution: Genes, Genealogies and Phylogenies. (New York: Cambridge University Press, 2013).

29 All the verses are taken from the Sahih International translation of the Quran. We should not that none of these verses explicitly refer to Adam. As such they can be taken to describe the creation of all humans, which is of course is compatible with evolution since we do not spontaneously come out of clay. Traditionally these verses usually are taken to refer to Adam, we follow this tradition in paper.

$30 \quad$ Al-Hajj 22/5.

31 Ar-Rahmān 55/14.

32 Al-Hijr 15/26.
} 
the earth and settled you in it, so ask forgiveness of Him and then repent to Him. Indeed, my Lord is near and responsive."'"133

Traditionally it is believed that after God created Adam from the clay, he breathed a spirit/life (ruh) into Adam. Here are some verses from the Qur'an which support this claim: "And [mention, o Muhammad], when your Lord said to the angels, "I will create a human being out of clay from an altered black mud. And when I have proportioned him and breathed into him of My [created] soul, then fall down to him in prostration." "34 "That is the Knower of the unseen and the witnessed, the Exalted in Might, the Merciful, Who perfected everything which He created and began the creation of man from clay. Then He made his posterity out of the extract of a liquid disdained. Then He proportioned him and breathed into him from His [created] soul and made for you hearing and vision and hearts [i.e., intellect]; little are you grateful." ${ }^{135}$

The Qur'an calls all the humans who are subject to the revelation "the children of Adam" (bani Adam). Thus, if we insist on a literal reading, we can conclude that all humans at the time of the revelation are descendants of Adam, a single person. Here are the relevant verses: "O children of Adam, let not Satan tempt you as he removed your parents from Paradise, stripping them of their clothing1 to show them their private parts. Indeed, he sees you, he and his tribe, from where you do not see them. Indeed, We have made the devils allies to those who do not believe." ${ }^{136}$ "Did I not enjoin upon you, O children of Adam, that you not worship Satan - [for] indeed, he is to you a clear enemy ..."137

Other verses in the Qur'an that, when read literally, seem to imply that all humans who are subject to the revelation are descendants of a single couple. Here are some representative verses: "O mankind, fear your Lord, who created you from one soul and created from it its mate and dispersed from both of them many men and women. And fear Allah, through whom you ask one another, and the wombs. Indeed, Allah is ever, over you, an Observer." 38 "O mankind, indeed, We have created you from male and female and made you peoples and tribes that you may know one another. Indeed, the most noble of you in the sight of Allah is the most righteous of you. Indeed, Allah is Knowing and Aware." ${ }^{139}$

Traditionally the term "its mate" in Qur'an 4:1 has been interpreted as referring to Eve. On the question of how Eve was created, there are two different interpretations. Some scholars have interpreted the term "from it" as referring to a part of the one soul, i.e., Adam. While the Qur'an does not mention it, this is usually read in accord with the Hebrew Bible's account of Eve being created out of Adam's rib. The second interpretation is to take the term to mean that Eve was created from the same kind as Adam ${ }^{40}$.

Hūd 11/61.

Al-Hijr 15/28-29.

As-Sajdah 32/6-9.

Al-A'rāf 7/27.

Yā-Sīn 36/60.

An-Nisā' 4/1.

Al-Hujurāt 49/13.

Malik, Islam and Evolution, 96. 
So the Qur'an seems to claim that Adam is created out of clay. But why should we assume that this did not happen via some process, perhaps through a billion years of evolution? Muslim creationists use several verses to argue against this. First, they point out that Adam is, the Qur'an states, created by the hands of God, which they interpret as the special, direct divine creation of Adam. Here is the relevant verse: "[Allah] said, "O Iblees, what prevented you from prostrating to that which I created with My hands? Were you arrogant [then], or were you [already] among the haughty?"'"41

Second, they refer to a verse which makes an analogy between Jesus and Adam, implying that Adam cannot have a father and therefore is specially created: "Indeed, the example of Jesus to Allah is like that of Adam. He created him from dust; then He said to him, "Be," and he was." 42

Third, some scholars point out a miracle attributed to Jesus in the Qur'an in which he transforms bird-shaped clay into a living bird. Even though the verse has no clear connection to the case of Adam, they think that the similarity between the cases, using clay as base material and breathing into it, suggests that Adam was also directly transformed from a human-shaped clay. "[The Day] when Allah will say, "O Jesus, Son of Mary, remember My favor upon you and upon your mother when I supported you with the Pure Spirit [i.e., the angel Gabriel] and you spoke to the people in the cradle and in maturity; and [remember] when I taught you writing and wisdom and the Torah and the Gospel; and when you designed from clay [what was] like the form of a bird with My permission, then you breathed into it, and it became a bird with My permission..." ${ }^{43}$ These are all the verses that are used against evolution.

Before finishing this section, let me summarize the Qur'an's alleged creation story of Adam. Adam is created from clay and the soul is injected into him, and God then creates Eve as a partner to him. Adam is appointed as vicegerent upon the earth. The Angels ask God why He appointed a vicegerent upon earth who would cause bloodshed. God reminds the angles that He knows what they do not know and teaches Adam the names of the things, knowledge unavailable to the angels. Then God asks the angels to bow down to Adam. Every angel bowed down except Iblis, who refused referring to his creation out of the fire which he thought is better than clay. God instructs Adam and Eve not to eat the fruit from a specific tree, but Iblis tricks them into eating the fruit. As a result, God expels them from the Garden. Whether the Garden is a place on earth or a Paradise outside of it is debated among Muslims. The more common opinion is that Garden is Paradise, rather than a garden here on earth, and that Adam and Eve were sent down on earth after they were expelled from the heavenly Garden.

This concludes the discussion of the relevant parts of the creation story of Adam as portrayed by Qur'an. From this discussion, two propositions emerge that may be in conflict with the common ancestor thesis:

1. Adam was directly and divinely created out of clay, and therefore, he does not have parents.

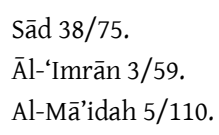


2. Adam is the ancestor of all the humans who are subject to the revelation.

In the next section, we will try to assess whether these two propositions are compatible with the common ancestor thesis. If they are compatible with it, we can conclude that evolution is compatible with a traditional reading of Islam.

\section{Double creation and the multiple ancestor defense}

Prima facie, it seems that common ancestry, which claims that humans share a common ancestor with all other animals and plants, is in tension with the claim that the common ancestor of all the humans is Adam, who was created directly out of clay. There are at least two scenarios in which these two claims can be reconciled.

First, one might claim that Adam was created two times, once in Paradise and, second, on earth. A similar strategy was used by Ibn Khaldun (1332-1406) in a different context. In response to a hadith in which it is mentioned that Adam was 60 cubits (approximately $40 \mathrm{~m}$ ) tall, Ibn Khaldun recognized that this description could not be true given earth conditions ${ }^{44}$. So he offered the interpretation that the Garden in which Adam was created was in Paradise and that Adam was 40 $m$ tall in Paradise, and then his height became normal when he descended to earth. This approach can be applied to the case of evolution. It is possible that the Qur'an describes Adam's creation in Paradise, while the theory of evolution describes humanity's creation on earth. ${ }^{45}$

Separating out the two creations of Adam/humanity eliminates a possible conflict between the Qur'anic and scientific narratives. Of course, Muslims thinkers should seek to connect the two creations. But the Qur'an does not give any details on how Adam was transferred from the Garden to the earth. So many different scenarios can be offered to connect the two narratives.

One way to connect the two narratives is the transmigration scenario. When God expelled Adam and Eve from Paradise, He may have transmigrated their souls from their bodies in Paradise to homo sapiens bodies that evolved on earth. The Qur'an does not have any official chronology like Archbishop Usher's Biblical chronology, so Adam may have lived at any time in the past. As such, he may have been placed at a critical time in the past so that all future generations who received revelation were descendants of Adam. This scenario involves both the Qur'anic narrative and the common descent thesis.

Transmigration is not the only possibility. Another possibility is the creation of Adam twice without any reference to the soul. Adam was created first in Paradise as described in the Qur'an, then after the fall recreated via evolutionary process here on earth ${ }^{46}$. The double creation defense

44 Ibn Haldun, Mukaddime, (İstanbul: Milli Eğitim Basımevi, 1997), 227-230.

45 I thank to anonymous referee who pointed out that Plato and the philosophers who followed him, thinkers like Yunus and Mevlana in the Islamic world, and eastern religions also argue that the body will be seen as a tool of the soul, and that people will return to the place where they came after death. According to this, the life of the world is actually nothing but the incarnation of the human soul. Death is not the end, it is the soul's liberation from the body and regaining its divine freedom. Therefore, this scenario is not new, on the contrary, it can be evaluated as a blending of a traditional teaching with the idea of evolution.

46 Again, I thank to anonymous referee who pointed out that this scenario can also be interpreted as God created Adam from earth as a prototype model in heaven and then turned it into mass production, so to speak, through evolution on earth. 
does not require belief that the Garden in which Adam was created was in Paradise. God may have created Adam here on earth directly from the clay, then after the fall, God may have recreated him again via an evolutionary process or transmigrated his soul to evolved homo sapiens. ${ }^{47}$

Muslims and non-Muslims alike may object that stories of the two creations of Adam, however construed, are implausible at best. But, for purposes of a defense of the consistency of Islam and evolution, all we need is a logically coherent story; the story need not be plausible to reject the inconsistency thesis.

The second objection to the inconsistency thesis is to take Adam's creation story literally but insist that humans share a common ancestor with other living things ${ }^{48}$. After all, we all have more than one ancestor. I call this scenario "the multiple ancestors defense." The idea is simple: there was a historical figure called Adam who was created in Paradise or on a garden here in earth. He underwent all the events described in the Qur'an. Separately from him, homo sapiens evolved ${ }^{49}$. At some point, both groups merged. The descendants of Adam mated with the evolved homo sapiens. By the time of the revelation, all of the homo sapiens living on earth were descendants of Adam and, at the same time, evolved homo sapiens. In this scenario both the scientific creation account and the scriptural accounts are correct. Thus, scriptural and scientific accounts are compatible. In this scenario creation of Adam is taken as a miracle, God created him out of clay with all the necessary biology so that his lineage can mate with evolved homo sapiens.

There may be two worries regarding the scenarios we presented. First of all, one may argue that they may imply that Adam is not the first human being. But this worry is groundless. First, the term "human" in the Qur'an (Insan) need not be equivalent to homo sapiens, it may be exclusively refer to the descendants of Adam. Second, the Qur'an may not take Adam to be the first human. Third, even if we insist that Adam must be the first human, the defenses can be easily modified to include this claim as well. Adam may have been teleported on earth from Paradise or created directly from the clay before homo sapiens evolved, and his much later descendants will be genetically mixed with evolved homo sapiens. Again, this story may seem implausible, but I am just arguing for consistency.

The second possible worry is that these scenarios seem to imply that some homo sapiens are not descendants of Adam. But Adam, in my stories, is the common ancestor of all the people at the time of the revelation (which the Qur'an claims). Therefore, the fact that some homo sapiens are not descendants of Adam is not a problem. Second, as mentioned above, the theological human need not be equivalent to homo sapiens; hence even if some homo sapiens are not descendants of Adam,

47 We should note that none of these scenarios conflict with science, as they can not be scientifically studied to be falsified or verified. Science does not have the power to investigate whether such a couple really lived.

48 Similar case seems to be defended by David Solomon Jalajel by appeal to the theological principle of tawaqquf. For his position see: David Solomon Jalajel, “Tawaqquf and Acceptance of Human Evolution.” (2018), Yaqeeninstitute, (Accessed August 1, 2021).

49 Here I use biological term homo sapiens instead of human, since human in scriptural context can have more specific meaning as I describe below. 
we can say that all humans in the Qur'anic sense are ${ }^{50}$. Third, and again, it is possible that Adam transmigrated from Paradise before the emergence of homo sapiens, so that when homo sapiens evolved, all were descendants of Adam. Thus, by modifying the defenses, it is possible to preserve the additional proposition, "All homo sapiens are descendants of Adam." Again, I want to remind that defenses need not be true or reasonable, it is sufficient they describe just logically possible scenarios.

\section{Conclusion}

In this paper, I argued that a literal reading of the Qur'an is compatible with the scientific theory of evolution. First, I asserted that the claim that the scriptural creation narrative is incompatible with the theory of evolution is analogous to the claim that classical theism is incompatible with the existence of evil (problem of evil). Using this analogy, I argued that rather than trying to find a complete and plausible account of how the Qur'anic narrative and the theory of evolution can both be true, we should search for more modest approaches which just aim to show that two accounts are compatible-similar to defenses in the context of the problem of evil. After sketching both the scientific as well as the scriptural accounts, and after arguing that the only potential conflict lies in the common ancestry thesis, I presented two defenses in which both accounts consistently coexist. In the first account, which I called "the double creation defense," I argued that Adam might have been created twice, once in Paradise as described in scripture and once on earth as described by evolutionary science. In the second defense, which I called "the multiple ancestors defense," I argued that God might have created Adam out of clay directly, with his descendants reproducing with evolved homo sapiens. As such, both creation narratives coexist without inconsistency.

50 There are several ways we can distinguish the theological human with generic homo sapiens. For example theological human can be homo sapiens with free will or with language capacity. It can be homo sapiens which was contacted by God via revelation. 


\section{Bibliography}

Altaie, Basil. The Divine Word and The Grand Design: Interpreting the Qur'ān in the Light of Modern Science. Manchester: Beacon Books. 2018.

Clark, Kelly James-Koperski, Jeffrey. Abrahamic Reflections on Randomness and Providence. Palgrave Macmillan. 2021.

Dajani, Rana. “Evolution and Islam's Quantum Question.” Zygon: Journal of Religion and Science, 47/2 (2012), 343-353.

Dalrymple, G. Brent. "The age of the Earth in the twentieth century: a problem (mostly) solved". Geological Society, London, Special Publications. 190/1 (2001), 205-221.

Finlay, Graeme. Human Evolution: Genes, Genealogies and Phylogenies. New York: Cambridge University Press. 2013.

Futuyma, Douglas-Kirkpatrick, Mark. Evolution. New York: Oxford University Press. 2018.

Guessoum, Nidhal. Islam's Quantum Question: Reconciling Muslim Tradition and Modern Science. London: I.B. Tauris. 2011.

Ibn Haldun. Mukaddime. İstanbul: Milli Eğitim Basımevi. 1997.

Jalajel, David Solomon. "Tawaqquf and Acceptance of Human Evolution.", Yaqeeninstitute, Accessed August 1, 2021. https://yaqeeninstitute.org/dr-david-solomon-jalajel/tawaqquf-andacceptance-of-human-evolution/\#.Xgw_HxczbPA

Keller, Nuh Ha Mim. Sea Without Shore: A Manual of the Sufi Path. Amman: Sunna Books. 2011.

Mackie, J. L. “Evil and Omnipotence.” Mind, 64 (1955), 200-212.

Malik, Shoaib. Islam and Evolution: Al-Ghazālī and the Modern Evolutionary Paradigm. New York: Routledge. 2021.

Mayr, Ernst. Towards a New Philosophy of Biology: Observations of an Evolutionist. Cambridge: Harvard University Press, 1988.

Nasr, Seyyed Hossein. “On the Question of Biological Origins.” Islam and Science, 4/2, (2006) 181197.

Plantinga, Alvin. God, Freedom, and Evil. Grand Rapids, MI: Eerdmans. 1977.

Qadhi, Yaser, and Khan, Nazir. "Human Origins: Theological Conclusions and Empirical Limitations." Yaqeeninstitute, Accessed July 29, 2021. https://yaqeeninstitute.org/nazirkhan/human-origins-theological-conclusions-and-empirical-limitations/

Sarkar, Sahotra. "Review of Seeking God in Science: An Atheist Defends Intelligent Design”. Notre Dame Philosophical Reviews (2011). Accessed December 11, 2021 https://ndpr.nd.edu/reviews/seeking-god-in-science-an-atheist-defends-intelligent-design/ 
Schopf, J. William. "Fossil evidence of Archaean life". Philosophical Transactions of the Royal Society B. 361/1470 (2006), 869-885.

Taslaman, Caner. Can a Muslim Be an Evolutionist? Istanbul: Istanbul Yayınevi. 2020.

The Quran, Trans. Saheeh International. Riyad: Saheeh International. 1997.

Tooley, Michael. "The Problem of Evil". The Stanford Encyclopedia of Philosophy (Spring 2019

Edition), Edward N. Zalta (ed.). (Accessed July 29, 2021)

https://plato.stanford.edu/archives/spr2019/entries/evil/ 